\title{
STUDI TENTANG LOYALITAS KONSUMEN OBAT SAKIT KEPALA PARAMEX DESA PANCORAN BONDOWOSO
}

\author{
Yudha Praja \\ Email : prajayudha9@gmail.com \\ Fakultas Ekonomi, Universitas Abdurachman Saleh
}

\begin{abstract}
Abstrak
Tujuan dari penelitian ini adalah untuk mengetahui pengaruh kepercayaan konsumen dan kualitas produk terhadap loyalitas konsumen obat Paramex di Desa Pancoran Bondowoso. Penelitian ini merupakan penelitian kuantitatif dengan pendekatan survei. Dengan jumlah sampel 90 responden. Hasil Penelitian secara parsial menunjukkan bahwa kepercayaan konsumen berpengaruh signifikan terhadap loyalitas konsumen dan promosi berpengaruh signifikan terhadap loyalitas konsumen. Secara simultan kualitas produk dan kepercayaan konsumen berpengaruh positif dan signifikan terhadap loyalitas konsumen. Sedangkan besarnya pengaruh variabel bebas terhadap variabel terikat dalam penelitian ini adalah $80,2 \%$.
\end{abstract}

Kata kunci : Kepercayaan Konsumen, Kualitas Produk, Loyalitas Konsumen

\section{PENDAHULUAN}

Perkembangan persaingan pasar yang pesat telah memicu perusahaan untuk mencari peluang guna meningkatkan loyalitas konsumen yang tercermin pada keuntungan yang diraih perusahaan tersebut. Salah satu strategi yang digunakan dalam mencapai loyalitas pelanggan ialah menggunakan strategi pemasaran yang mampu miningkatkan kepercayaan konsumen dan peningkatan kualitas produk yang ditawarkan.

Menurut Tjiptono (2011), Loyalitas konsumen adalah pembelian ulang suatu merek secara konsisten oleh konsumen. Loyalitas konsumen bisa muncul karena adanya kepuasan konsumen sebagai akibat dari layanan yang berkualitas yang memenuhi harapan pelanggan sehingga tidak beralih ke produk lain.

Peningkatan loyalitas konsumen terhadap produk juga disertai dengan kepercayaan konsumen atas produk tersebut. Sikap (attitudes) konsumen adalah faktor penting yang akan mempengaruhi keputusan konsumen. Konsep sikap sangat terkait dengan konsep kepercayaan (belief) dan perilaku (behavior). 
Mowen dan Minor menyebutkan istilah pembentukan sikap konsumen seringkali menggambarkan hubungan antara kepercayaan, sikap, dan perilaku. Kepercayaan, sikap, dan perilaku juga terkait dengan konsep atribut produk.

Selain kepercayaan konsumen, kualitas produk juga sangat berpengaruh dalam meningkatkan loyalitas konsumen, Kualitas produk adalah sejauh mana produk memenuhi spesifikasi - spesifikasinya (Lupiyoadi, 2009). Produk memiliki arti penting bagi perusahaan karena tanpa adanya produk, perusahaan tidak akan dapat melakukan apapun dari usahanya. Konsumen cenderung membeli produk jika merasa cocok, karena itu produk harus disesuaikan dengan keinginan atau kebutuhan pembeli agar pemasaran produk berhasil. Menurut Kotler dan Armstrong (2014) "Kualitas produk adalah karakter yang dimiliki sebuah produk yang mempunyai kemampuan untuk memenuhi kebutuhan pelanggan".

Berdasarkan teori peningkatan penjualan diatas, maka objek penelitian yang dipilih ialah pada konsumen oabt sakit kepala Paramex di Desa Pancoran Kecamatan Pancoran Kabupaten Bondowoso. Konimex adalah salah satu perusahaan farmasi Nasional yang didirikan pada 8 Juni 1967 sebagai perusahaan perdagangan jual beli obat-obatan, bahan kimia, alat laboratorium dan alat kedokteran. PT Konimex berlokasi di desa Sanggrahan, Kecamatan Grogol, kabupaten Sukoharjo, Jawa Tengah yang dibangun pada tahun 1979. Setahun kemudian, 1980, di kompleks baru ini didirikan pabrik kembang gula Nimm's yang menjadi awal diversifikasi Konimex ke industri makanan. Mengikuti peraturan pemerintah yang mengharuskan pemisahan antara produsen obat dengan distributornya, pada tahun 1980 Konimex mendirikan PT Sinar Intermark. Kemudian, untuk memperluas jangkauan distribusi dan sejalan dengan semakin banyaknya produk yang dipasarkan, tahun 1986, Konimex mendirikan perusahaan distributor yang kedua, PT Marga Nusantara Jaya. Satu dasawarsa kemudian, pada tahun 1994, didirikan pabrik biskuit Sobisco, yang memproduksi produk-produk makanan. 
Adapun produk-produk obat bebas (over the counter) : diantaranya adalah Paramex, Paramex Sakit Kepala, Paramex Flu dan Batuk, Paramex Nyeri Otot dan lain-lain, Paramex produk andalan dari Konimex yang berisikan: Paracetamol 250 mg Propyphenazone $150 \mathrm{mg}$ Caffeine $50 \mathrm{mg}$ Dexchlorpheniramine Maleate $1 \mathrm{mg}$ yang sudah terbukti manjur untuk menghadapi sakit kepala yang membandel. Paramex bisa digunakan juga untuk menghilangkan nyeri pada penderita sakit gigi. Paramex adalah obat sakit kepala dan pereda nyeri yang luar biasa, Paramex adalah TOP BRAND untuk obat sakit kepala

Berdasarkan data TOP BRAND dapat diketahui bahwa data penjualan obat Paramex menduduki posisi tiga setelah bodrex daan panadol dan diikuti produk lain setelah Paramex, selain itu Paramex dengan jumlah penjuan yang semakin tahun terjadi fluktuatif penjualan dengan nilai indek Tahun 2016 24.2\% pada posisi ke dua, Tahun 2017 22.4\% pada ada posisi ke tiga, Tahun 2018 22.0\% pada ada posisi ke tiga. Berdasarkan data TOP BRAND, maka peneliti mendapatkan fenomena penjualan ialah masih terjadinya fluktuatif penjualan obat sakit kepala TOP BRAND Paramex, sehingga dalam penelitian ini peneliti berusaha memberikan solusi untuk meningkatkan volume penjualan dengan mengacu pada faktor yang dianggap penting ialah Trust dan Kualitas produk yang diasumsikan mampu meningkatkan loyalitas konsumen dalam pembelian obat Paramex jika mengalami sakit kepala.

\section{METODE PENELITIAN}

Jenis penelitian yang digunakan adalah penelitian penjelasan (explanatory research) dan penelitian konfirmatori (confirmatory research), confirmatory research adalah penelitian yang bertujuan menguji hubungan teoritis antara variable berdasarkan data empiris melalui pengujian hipotesis.

Jenis data yang dianalisis dalam penelitian ini adalah data primer. Data primer dalam penelitian ini adalah berupa jawaban dari pertanyaan kuisioner dan wawancara terhadap konsumen obat sakit kepala Paramex Desa Pancoran Bondowoso. Metode pengumpulan data dalam studi ini dilakukan dengan 
menggunakan metode survei, yakni menggunakan kuisoner yang berisi butir-butir pengukuran konstruk atau variable yang digunakan dalam metode penelitian ini. Pengumpulan data dilakukan secara langsung dengan meminta kesediaan responden untuk mengisi kuisoner yang dilakukan dengan mendatangi konsumen obat sakit kepala Paramex Desa Pancoran - Bondowoso.

Populasi dalam penelitian ini adalah konsumen obat sakit kepala Paramex Desa Pancoran - Bondowoso yang jumlahnya tidak dapat dipastikan. Menurut Roscoe (1975) yang dikutip Uma Sekaran (2006) memberikan acuan umum untuk menentukan ukuran sampel. Ukuran sampel lebih dari 30 dan kurang dari 500 adalah tepat untuk kebanyakan penelitian. Teknik pengambilan sampel yang digunakan dalam penelitian ini adalah judgment sampling. Tahap pertama pengambilan sampel adalah siapa saja yang kebetulan bertemu dengan peneliti (diperoleh dengan mudah) dan tahap berikutnya adalah bila responden tersebut cocok sebagai sumber data dengan pertimbangan tertentu. Pertimbangan yang digunakan dalam memilih responden berdasarkan ketentuan bahwa responden dalam penelitian ini adalah konsumen yang pernah dan cocok saat mengkonsumsi obat sakit kepala Paramex. Jumlah sample dalam penelitian ini adalah 90 responden.

Analisis data yang digunakan untuk menjawab rumusan masalah dalam penelitian ini adalah metode kuantitatif yaitu dilakukan dengan regresi linier berganda dengan alat bantu software program SPSS.

\section{HASIL PENELITIAN DAN PEMBAHASAN}

\section{Hasil Analisis Data}

\section{Pengujian Validitas}

Uji validitas digunakan untuk menguji sejauh mana ketepatan alat pengukur dapat mengungkapkan konsep gejala/kejadian yang diukur.Item kuesioner dinyatakan valid apabila nilai r-hitung > r-tabel (n-2). Pengujian validitas selengkapnya dapat dilihat pada tabel 1 berikut ini: 
Tabel 1.Hasil Pengujian Validitas

\begin{tabular}{cccc}
\hline Variabel & r-hitung & r-tabel & Keterangan \\
\hline X1.1 & 0,858 & 0,325 & Valid \\
X1.2 & 0,738 & 0,325 & Valid \\
X1.3 & 0,712 & 0,325 & Valid \\
X2.1 & 0,804 & 0,325 & Valid \\
X2.2 & 0,633 & 0,325 & Valid \\
X2.3 & 0,799 & 0,325 & Valid \\
X2.4 & 0,610 & 0,325 & Valid \\
X2.5 & 0,856 & 0,325 & Valid \\
Y1.1 & 0,811 & 0,325 & Valid \\
Y1.2 & 0,871 & 0,325 & Valid \\
Y1.3 & 0,782 & 0,325 & Valid \\
\hline
\end{tabular}

Sumber: Data primer yang diolah 2018

Tabel 1 menunjukkan bahwa korelasi antara masing-masing indikator terhadap total skor konstruk dari setiap variabel menunjukkan hasil yang signifikan, dan menunjukkan bahwa $\mathrm{r}$ hitung $>\mathrm{r}$ tabel. Sehingga dapat disimpulkan bahwa semua item pertanyaan dinyatakan valid.

\section{Pengujian Reliabilitas}

Uji reliabilitas digunakan untuk menguji sejauh mana keandalan suatu alat pengukur untuk dapat digunakan lagi untuk penelitian yang sama. Pengujian reliabilitas dalam penelitian ini adalah dengan menggunakan rumus Alpha. Hasil pengujian reliabilitas untuk masing-masing variabel yang diringkas pada tabel 2 berikut ini:

Tabel 2 Hasil Pengujian Reliabilitas

\begin{tabular}{ccc}
\hline Variabel & Alpha & Keterangan \\
\hline Kepercayaan konsumen (X1) & 0,689 & Reliabel \\
Kualitas produk (X2) & 0,801 & Reliabel \\
Loyalitas konsumen (Y) & 0,759 & Reliabel \\
\hline
\end{tabular}

Sumber: Data primer yang diolah 2018

Hasil uji reliabilitas tersebut menunjukkan bahwa semua variabel mempunyai koefisien Alpha yang cukup besar yaitu diatas 0,60 sehingga dapat dikatakan semua konsep pengukur masing-masing variabel dari kuesioner adalah 
reliabel sehingga untuk selanjutnya item-item pada masing-masing konsep variabel tersebut layak digunakan sebagai alat ukur.

\section{Analisis Persamaan Regresi Linear Berganda}

Model persamaan regresi yang baik adalah yang memenuhi persyaratan asumsi klasik, antara lain semua data berdistribusi normal, model harus bebas dari gejala multikolinieritas dan terbebas dari heterokedastisitas. Dari analisis sebelumnya telah terbukti bahwa model persamaan yang diajukan dalam penelitian ini telah memenuhi persyaratan asumsi klasik sehingga model persamaan dalam penelitian ini sudah dianggap baik. Analisis regresi digunakan untuk menguji hipotesis tentang pengaruh secara parsial variabel bebas terhadap variabel terikat. Berdasarkan estimasi regresi berganda dengan program SPSS 21 diperoleh hasil seperti tabel 3.

Tabel 3 Hasil Estimasi Regresi

Coefficients $^{\mathrm{a}}$

\begin{tabular}{|c|c|c|c|c|c|c|}
\hline \multirow[b]{2}{*}{ Model } & \multicolumn{2}{|c|}{$\begin{array}{l}\text { Unstandardized } \\
\text { Coefficients }\end{array}$} & \multirow[b]{2}{*}{$\mathrm{t}$} & \multirow[b]{2}{*}{ Sig. } & \multicolumn{2}{|c|}{ Collinearity Statistics } \\
\hline & B & Std. Error & & & Tolerance & VIF \\
\hline 1(Constant) & .395 & .528 & .747 & .457 & & \\
\hline $\mathrm{X} 1$ & .278 & .067 & 4.127 & .000 & .275 & 3.635 \\
\hline $\mathrm{X} 2$ & .341 & .055 & 6.241 & .000 & .275 & 3.635 \\
\hline
\end{tabular}

a. Dependent

Variable: Y

Sumber: Data primer yang diolah 2019

Berdasarkan tabel 3 dapat diketahui persamaan regresi yang terbentuk adalah:

$$
\mathrm{Y}=0,395+0,278 \mathrm{X} 1+0,341 \times 2+\mathrm{e}
$$

Keterangan:

$\mathrm{Y}=$ Loyalitas konsumen

$\mathrm{X} 1$ = Kepercayaan konsumen

$\mathrm{X} 2=$ Kualitas produk 
Dari persamaan tersebut dapat dijelaskan bahwa:

a. Variabel kepercayaan konsumen dan kualitas produk mempunyai arah koefisien yang bertanda positif terhadap loyalitas konsumen.

b. Koefisien kepercayaan konsumen memberikan nilai sebesar 0,278 yang berarti bahwa jika kepercayaan konsumen semakin baik dengan asumsi variabel lain tetap maka loyalitas konsumenakan mengalami peningkatan.

c. Koefisien kualitas produk memberikan nilai sebesar 0,341 yang berarti bahwa jika kualitas produk semakin kuat dengan asumsi variabel lain tetap maka loyalitas konsumen akan mengalami peningkatan.

\section{Uji F (Pengujian hipotesis secara simultan)}

Untuk menguji pengaruh variabel bebas secara bersama-sama diuji dengan menggunakan uji F. Hasil perhitungan regresi secara simultan diperoleh sebagai berikut:

Tabel 4 Hasil analisis regresi secara simultan ANOVA $^{b}$

\begin{tabular}{|l|r|r|r|r|r|}
\hline Model & Sum of Squares & df & Mean Square & F & Sig. \\
\hline $1 \quad$ Regression & 240.763 & 2 & 120.382 & 181.431 & $.000^{\text {a }}$ \\
Residual & 57.726 & 87 & .664 & & \\
Total & 298.489 & 89 & & & \\
\hline
\end{tabular}
a. Predictors: (Constant), X2, X1
b. Dependent Variable: Y

Sumber: Data primer yang diolah 2018

Pengujian pengaruh variabel bebas secara bersama-sama terhadap variabel terikatnya dilakukan dengan menggunakan uji F. Hasil perhitungan statistic menunjukkan nilai $\mathrm{F}$ hitung $=181,431$. Dengan menggunakan batas signifikansi 0,05, maka diperoleh nilai signifikansi tersebut lebih kecil dari 0,05. Hal ini berarti bahwa hipotesis yang menyatakan bahwa secara simultan variabel kepercayaan konsumen dan kualitas produk mempunyai pengaruh terhadap loyalitas konsumen. 


\section{Koefisien Determinasi $\left(\mathbf{R}^{2}\right)$}

Koefisien determinasi merupakan besaran yang menunjukkan besarnya variasi variabel dependen yang dapat dijelaskan oleh variabel independennya. Dengan kata lain, koefisien determinasi ini digunakan untuk mengukur seberapa jauh variabel-variabel bebas dalam menerangkan variabel terikatnya. Nilai koefisien determinasi ditentukan dengan nilai adjusted $R$ square sebagaimana dapat dilihat pada tabel 5:

Tabel 5 Koefisien Determinasi

Model Summary ${ }^{b}$

\begin{tabular}{|l|r|r|r|r|}
\hline Model & $\mathrm{R}$ & $\mathrm{R}$ Square & Adjusted R Square & \multicolumn{1}{c|}{$\begin{array}{c}\text { Std. Error of the } \\
\text { Estimate }\end{array}$} \\
\hline 1 & $.898^{\mathrm{a}}$ & .807 & .802 & .81456 \\
\hline
\end{tabular}

a. Predictors: (Constant), X2, X1

b. Dependent Variable: Y

Sumber: Data primer yang diolah 2018

Hasil perhitungan regresi dapat diketahui bahwa koefisien determinasi (adjusted $R 2$ ) yang diperoleh sebesar 0,802. Hal ini berarti 80,2\% variasi variabel loyalitas konsumen dapat dijelaskan oleh variabel kepercayaan konsumen dan kualitas produk sedangkan sisanya sebesar 19,8\% diterangkan oleh variabel lain yang tidak diajukan dalam penelitian ini.

\section{Uji t ( Uji Hipotesis Secara Parsial )}

Hipotesis 1 dan 2 dalam penelitian ini diuji kebenarannya dengan menggunakan uji parsial. Pengujian dilakukan dengan melihat taraf signifikansi (p-value), jika taraf signifikansi yang dihasilkan dari perhitungan di bawah 0,05 maka hipotesis diterima, sebaliknya jika taraf signifikansi hasil hitung lebih besar dari 0,05 maka hipotesis ditolak. 
Tabel 6. Hasil Uji t Secara Parsial

\begin{tabular}{crr}
\hline Variabel Bebas & t-hitung & Sig. t \\
\hline Kepercayaan konsumen (X1) & 4,127 & 0,000 \\
Kualitas produk (X2) & 6,241 & 0,000 \\
\hline
\end{tabular}

Sumber: Data primer yang diolah 2018

\section{Uji Hipotesis 1 ( H1 )}

Perumusan hipotesis:

Ho $: \beta \mathrm{i}=0$ tidak ada pengaruh positif antara kepercayaan konsumen dengan loyalitas konsumen.

$\mathrm{Ha}: \beta \mathrm{i}>0$ terdapat pengaruh positif antara kepercayaan konsumen dengan loyalitas konsumen.

Dari tabel 6 terlihat bahwa hasil pengujian hipotesis kepercayaan konsumen menunjukkan nilai t hitung sebesar 4,127 dengan taraf signifikansi 0,000. Taraf signifikansi tersebut lebih kecil dari 0,05, yang berarti bahwa hipotesis dalam penelitian ini menolak Ho dan menerima Ha. Dengan demikian dapat berarti bahwa hipotesis H1 "kepercayaan konsumen mempunyai pengaruh positif terhadap loyalitas konsumen“ diterima.

\section{Uji Hipotesis 2 ( $\mathrm{H} 2$ )}

Perumusan hipotesis:

Ho $: \beta \mathrm{i}=0$ tidak ada pengaruh positif antara kualitas produk dengan loyalitas konsumen.

$\mathrm{Ha}: \beta \mathrm{i}>0$ terdapat pengaruh positif antara kualitas produk dengan loyalitas konsumen.

Dari tabel 6 terlihat bahwa hasil pengujian hipotesis kualitas produk menunjukkan nilai t hitung sebesar 6,241 dengan taraf signifikansi 0,000. Taraf signifikansi hitung tersebut lebih kecil dari 0,05, yang berarti bahwa hipotesis dalam penelitian ini menolak Ho dan menerima Ha. Dengan demikian berarti bahwa hipotesis H2 "kualitas produk mempunyai pengaruh positif terhadap loyalitas konsumen“" diterima. 


\section{Uji Asumsi Klasik}

\section{a. Uji Multikolinieritas}

Pengujian multikolinieritas bertujuan untuk mengetahui hubungan yang sempurna antar variabel bebas dalam model regresi. Gejala multikolinieritas dapat dilihat dari nilai tolerance dan nilai Varian Inflation Factor (VIF). Bila nilai VIF lebih kecil dari 10 dan nilai toleransinya di atas 0,1 atau $10 \%$ maka dapat disimpulkan bahwa model regresi tersebut tidak terjadi multikolinieritas (Ghozali, 2005).

Tabel 7. Hasil Uji Multikolinieritas

\begin{tabular}{ccc}
\hline Variabel Bebas & Toleransi & VIF \\
\hline Kepercayaan konsumen (X1) & 0,275 & 3,635 \\
Kualitas produk (X2) & 0,275 & 3,635 \\
\hline
\end{tabular}

Sumber: Data primer yang diolah 2018

Dari tabel tersebut menunjukkan bahwa nilai VIF semua variabel bebas dalam penelitian ini lebih kecil dari 10 sedangkan nilai toleransi semua variabel bebas lebih dari $10 \%$ yang berarti tidak terjadi korelasi antar variabel bebas yang nilainya lebih dari 90\%, dengan demikian dapat disimpulkan bahwa tidak terdapat gejala multikolinieritas antar variabel bebas dalam model regresi.

\section{b Uji Heteroskedastisitas}

Uji ini bertujuan untuk menguji apakah dalam sebuah model regresi terjadi ketidaksamaan varians dari residual, dari satu pengamatan ke pengamatan yang lain. Jika varians dari residual dari satu pengamatan ke pengamatan yang lain tetap, maka disebut homoskedastisitas dan jika varians berbeda, disebut heterokedastisitas. Model regresi yang baik adalah tidak terjadi heterokedastisitas. Untuk mendeteksi ada tidaknya heterokedastisitas dapat digunakan metode grafik Scatterplot yang dihasilkan dari output program SPSS versi 17, Apabila pada gambar menunjukkan bahwa titik-titik menyebar secara acak serta tersebar baik di atas maupun di bawah angka 0 pada sumbu Y, maka hal ini dapat disimpulkan tidak terjadi adanya heterokedastisitas pada model regresi (Ghozali, 2005). 


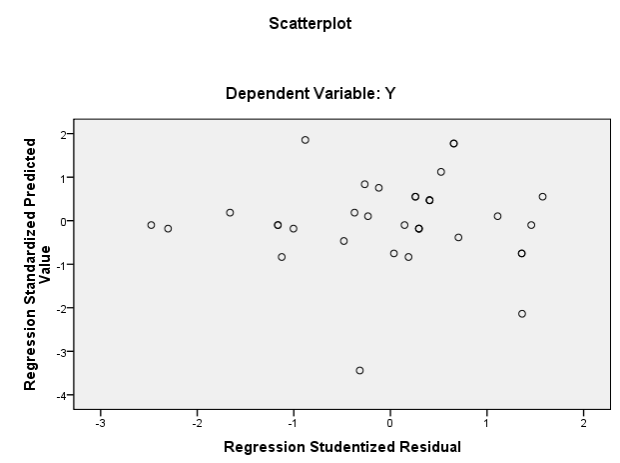

Gambar 1 Hasil Pengujian Heterokedastisitas Sumber: Data primer yang diolah 2018

Dari grafik tersebut terlihat titik-titik yang menyebar secara acak, tidak membentuk suatu pola tertentu yang jelas, serta tersebar baik di atas maupun di bawah angka 0 (nol) pada sumbu $\mathrm{Y}$, hal ini berarti tidak terjadi penyimpangan asumsi klasik heterokedastisitas pada model regresi yang dibuat, dengan kata lain menerima hipotesis homoskedastisitas.

\section{c. Uji Normalitas}

Uji normalitas bertujuan untuk menguji apakah dalam model regresi, variabel bebas dan variabel terikat, keduanya terdistribusikan secara normal ataukah tidak. Normalitas data dalam penelitian dilihat dengan cara memperhatikan titik-titik pada Normal P-Plot of Regression Standardized Residual dari variabel terikat. Persyaratan dari uji normalitas adalah jika data menyebar di sekitar garis diagonal dan mengikuti arah garis diagonal, maka model regresi memenuhi asumsi normalitas. Jika data menyebar jauh dari garis diagonal dan/atau tidak mengikuti garis diagonal, maka model regresi tidak memenuhi asumsi normalitas. 
Normal P-P Plot of Regression Standardized Residual

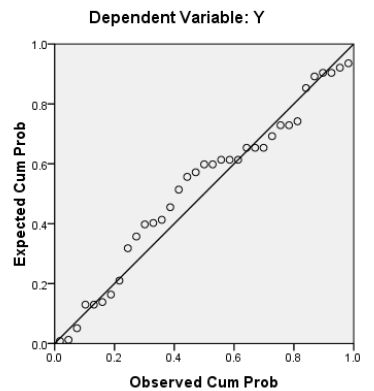

Gambar 2 Hasil Pengujian Normalitas Sumber: Data primer yang diolah 2018

Dari gambar tersebut didapatkan hasil bahwa semua data berdistribusi secara normal, sebaran data berada disekitar garis diagonal.

\section{PEMBAHASAN}

Berdasarkan hasil pengujian secara statistik dapat terlihat dengan jelas bahwa secara parsial (individu) semua variabel bebas berpengaruh terhadap variabel terikat. Pengaruh yang diberikan kedua variabel bebas tersebut bersifat positif artinya semakin tinggi kepercayaan konsumen dan kualitas produk maka mengakibatkan semakin tinggi pula loyalitas konsumen yang dihasilkan. Hasil tersebut sesuai dengan hipotesis yang diajukan. Hasil penelitian ini juga sesuai dengan hasil penelitian sebelumnya. Penjelasan dari masing-masing pengaruh variabel dijelaskan sebagai berikut:

\section{a. Pengaruh Kepercayaan Konsumen terhadap Loyalitas Konsumen}

Hasil pengujian hipotesis (H1) telah membuktikan terdapat pengaruh antara kepercayaan konsumen terhadap loyalitas konsumen. Melalui hasil perhitungan yang telah dilakukan diperoleh nilai t hitung sebesar 4,127dengan taraf signifikansi hasil sebesar 0,000. Taraf signifikansi tersebut lebih kecil dari 0,05, dengan demikian Ha diterima dan Ho ditolak. Pengujian ini secara statistik membuktikan bahwa kepercayaan konsumen berpengaruh positif terhadap loyalitas konsumen. Artinya bahwa ada pengaruh antara variabel kepercayaan 
konsumen terhadap loyalitas konsumen obat sakit kepala Paramex di Desa Pancoran Kabupaten Bondowoso. Hasil ini mendukung penelitian sebelumnya yang menyatakan bahwa kepercayaan konsumen berpengaruh positif dan signifikan terhadap minat beli ulang.

\section{b. Pengaruh Kualitas produk terhadap Loyalitas konsumen}

Hasil pengujian hipotesis (H2) telah membuktikan terdapat pengaruh antara kualitas produk terhadap loyalitas konsumen. Melalui hasil perhitungan yang telah dilakukan didapat nilai t hitung sebesar 6,241dengan taraf signifikansi hitung sebesar 0,000. Taraf signifikansi tersebut lebih kecil dari 0,05, yang berarti bahwa hipotesis dalam penelitian ini menolak Ho dan menerima Ha, Pengujian ini secara statistik membuktikan bahwa kualitas produk berpengaruh positif terhadap loyalitas konsumen. Artinya bahwa ada pengaruh antara variabel kualitas produk terhadap loyalitas konsumenobat sakit kepala Paramex di Desa Pancoran Kabupaten Bondowoso. Hasil ini mendukung penelitian sebelumnya dengan hasil analisis yaitu kualitas produk memiliki pengaruh terhadap minat beli.

\section{c. Pengaruh Kepercayaan konsumen dan Kualitas produk Terhadap Loyalitas konsumen.}

Hasil pengujian hipotesis (H3) telah membuktikan terdapat pengaruh antara Kepercayaan konsumen dan kualitas produk, terhadap loyalitas konsumen. Melalui hasil perhitungan yang telah dilakukan diperoleh nilai $\mathrm{F}$ hitung sebesar 181,431 dengan taraf signifikansi hasil sebesar 0,000 tersebut lebih kecil dari 0,05 , yang berarti bahwa hipotesis dalam penelitian ini menerima Ha dan menolak Ho. Pengujian ini secara statistic membuktikan bahwa ada pengaruh antara Kepercayaan konsumen dan Kualitas produk berpengaruh positif terhadap loyalitas konsumen. Artinya bahwa ada pengaruh antara variabel secara simultan terhadap loyalitas konsumen obat sakit kepala Paramex di Desa Pancoran Kabupaten Bondowoso. Hasil ini mendukung penelitian sebelumnya yang menyatakan bahwa ada pengaruh positif dan signifikan antara variabel secara silmultan terhadap loyalitas konsumen. 


\section{PENUTUP}

\section{Kesimpulan}

Dari data primer yang diperoleh dari penyebaran kuesioner maka dilakukan pengujian reliabilitas untuk mengetahui bahwa jawaban responden terhadap pernyataan konsisten dari waktu ke waktu dan dilakukan pengujian validitas untuk mengukur sah tidaknya suatu kuesioner. Hasil dari uji reliabilitas dan validitas menunjukkan bahwa seluruh pernyataan dalam setiap variabel reliabel dan valid.

Dalam uji asumsi klasik yang meliputi uji multikolonieritas, uji heteroskedastisitas dan uji normalitas menunjukkan bahwa dalam model regresi tidak ditemukan adanya korelasi antar variabel bebas dan tidak terjadi heteroskedastisitas serta memiliki distribusi normal.

Dari pembahasan yang telah diuraikan, maka dapat ditarik kesimpulan berikut:

1. Hasil pengujian hipotesis (H1) telah membuktikan terdapat pengaruh antara kepercayaan konsumen terhadap loyalitas konsumen. Melalui hasil perhitungan yang telah dilakukan diperoleh nilai t hitung sebesar 4,127 dengan taraf signifikansi hasil sebesar 0,000. Taraf signifikansi tersebut lebih kecil dari 0,05, dengan demikian Ha diterima dan Ho ditolak. Pengujian ini secara statistik membuktikan bahwa kepercayaan konsumen berpengaruh positif terhadap loyalitas konsumen. Artinya bahwa ada pengaruh antara variabel kepercayaan konsumen terhadap loyalitas konsumen Obat sakit kepala Paramex di Desa Pancoran Kabupaten Bondowoso.

2. Hasil pengujian hipotesis $(\mathrm{H} 2)$ telah membuktikan terdapat pengaruh antara kualitas produk terhadap loyalitas konsumen. Melalui hasil perhitungan yang telah dilakukan didapat nilai t hitung sebesar 6,241dengan taraf signifikansi hitung sebesar 0,000. Taraf signifikansi tersebut lebih kecil dari 0,05, yang berarti bahwa hipotesis dalam penelitian ini menolak Ho dan menerima Ha, Pengujian ini secara statistik membuktikan bahwa kualitas produk berpengaruh positif terhadap loyalitas konsumen. Artinya bahwa ada 
pengaruh antara variabel kualitas produk terhadap loyalitas konsumen Obat sakit kepala Paramex di Desa Pancoran Kabupaten Bondowoso.

3. Hasil pengujian hipotesis (H3) telah membuktikan terdapat pengaruh antara Kepercayaan konsumen dan kualitas produk, terhadap loyalitas konsumen. Melalui hasil perhitungan yang telah dilakukan diperoleh nilai $\mathrm{F}$ hitung sebesar 54,039 dengan taraf signifikansi hasil sebesar 0,000 tersebut lebih kecil dari 0,05, yang berarti bahwa hipotesis dalam penelitian ini menerima Ha dan menolak Ho. Pengujian ini secara statistic membuktikan bahwa ada pengaruh antara Kepercayaan konsumen dan Kualitas produk berpengaruh positif terhadap loyalitas konsumen. Artinya bahwa ada pengaruh antara variabel secara simultan terhadap loyalitas konsumen Obat sakit kepala Paramex di Desa Pancoran Kabupaten Bondowoso.

4. Kualitas produk memiliki pengaruh yang paling kuat terhadap loyalitas konsumen Obat sakit kepala Paramex di Desa Pancoran Kabupaten Bondowoso.

\section{Saran}

Dari hasil penelitian ini kiranya dapat memberikan saran diantaranya :

1. Hasil penelitian membuktikan bahwa kepercayaan konsumen dan kualitas produk mempunyai pengaruh yang positif dan signifikan terhadap loyalitas konsumen, oleh karena itu hendaknya produsen Obat sakit kepala Paramex, selalu memperhatikan hal-hal khususnya yang berkaitan dengan kepercayaan konsumen dan kualitas produk.

2. Hasil penelitian membuktikan bahwa faktor kualitas produk merupakan faktor yang dominan terhadap kepuasam konsumen Obat sakit kepala Paramex di Desa Pancoran Kabupaten Bondowoso. Oleh karena itu pihak produsen Paramex harus berupaya mempertahankan dan meningkatkan aspek-aspek yang berkaitan dengan loyalitas konsumen seperti kesesuaian kepercayaan konsumen dan kualitas produk dengan harapan konsumen agar dapat meningkatakan loyalitas konsumen. 
3. Bagi Penelitian Selanjutnya Hasil Uji R2 menunjukkan masih ada variabel-variabel lain yang harus diperhatikan dalam penelitian ini. Penelitian-penelitian lebih lanjut, hendaknya menambah variabel lain yang dapat mempengaruhi loyalitas konsumen, karena dengan semakin baik loyalitas konsumen maka akan berpengaruh baik juga bagi perusahaan/organisasi.

\section{Daftar Pustaka}

Ghozali, Imam. 2005. Aplikasi Analisis Multivariate dengan SPSS. Semarang: Badan Penerbit UNDIP.

Kotler, Philip \& Gerry Armstrong, (2014): Principle Of Marketing, 15th edition. New Jersey: Pearson Pretice

Lupiyoadi, 2009. Manajemen Pemasaran Jasa, Salemba. Empat, Jakarta,

Sekaran, U. (2006). Metode Penelitian Untuk Bisnis 1. (4th ed).Jakarta: Salemba. Empat.

Tjiptono,(2011), Pemasaran Jasa, Bayumedia, Malang. 